\title{
Lise Öğrencilerinin İngilizceye Yönelik Öz Yeterlik İnançlarının ve Yabancı Dil Öğrenme Kaygılarının İncelenmesi: Bir Anadolu Lisesi Örneği ${ }^{1 *}$
}

\author{
Rabia ÇETINTAŞ \\ Öğretmen, Mevlana Anadolu Lisesi, \\ rb.ctnts88@gmail.com \\ Orcid ID: https//orcid.org/0000-0003-3836-5403 \\ Hasan Güner BERKANT \\ Prof. Dr., Yozgat Bozok Üniversitesi, \\ Eğitim Fakültesi, Eğitim Bilimleri Bölümü \\ hgberkant@gmail.com \\ Orcid ID: https//orcid.org/0000-0003-0725-6036
}

\section{$\ddot{\mathbf{O} z}$}

$\mathrm{Bu}$ araştırmanın amacı, lise öğrencilerinin İngilizce ile ilgili öz yeterlik algılarının ve yabancı dil öğrenme kaygılarının incelenmesidir. Araştırmada ilişkisel tarama modeli kullanılmıştır. Araştırmanın örneklemini kolay ulaşılabilir örnekleme yoluyla seçilen 686 öğrenci oluşturmaktadır. Araştırma verileri "Kişisel Bilgi Formu", "İngilizce ile İlgili Öz Yeterlik Algısı Ölçeği” ve "Yabancı Dil Öğrenme Kaygısı Ölçeği’" kullanılarak toplanmıştır. Araştırmanın alt amaçlarına uygun olarak betimsel istatistikler, ilişkisiz örneklemler için tek yönlü varyans analizi, bağımsız gruplar t-testi, LSD testi, Tukey testi, Kruskal Wallis-H testi, Mann Whitney U testi ve basit korelasyon analizi kullanılmıştır. Araştırma sonucunda lise öğrencilerinin İngilizce öz yeterlik algıları arasında sınıf düzeyi, ailenin maddi geliri, İngilizce kursuna gitme durumu ve İngilizce dersine çalışma sıklığ değiş̧kenlerine göre anlamlı fark olduğu belirlenirken; cinsiyet değişkenine göre anlamlı fark tespit edilmemiştir. Bunun yanı sıra lise öğrencilerinin yabancı dil öğrenme kaygıları arasında cinsiyet, sınıf düzeyi, İngilizce kursuna gitme durumu ve İngilizce dersine çalışma sıklı̆̆ 1 değişkenlerine göre anlamlı farklılık tespit edilirken, aile maddi geliri değişkenine göre anlamlı fark tespit edilmemiştir. Lise öğrencilerinin İngilizce

\footnotetext{
${ }^{1}$ Makale Geliş/Kabul Tarihi: 26.04.2021/21/12/2021

* Bu makale, Rabia ÇETINTTAŞ'ın KSÜ Sosyal Bilimler Ensitüsü'nde tamamladığı yüksek lisans tezinden üretilmiştir.

Künye Bilgisi: Çetintaş, R. ve Berkant, H. G. (2021). Lise öğrencilerinin İngilizceye yönelik öz yeterlik inançlarının ve yabancı dil öğrenme kaygılarının incelenmesi: Bir Anadolu lisesi örneği. Kahramanmaraş Sütçü Imam Üniversitesi Sosyal Bilimler Dergisi, 18 (3), 1545-1571. DOI: 10.33437/ksusbd.928516.
} 
öz yeterlik algıları ile yabancı dil öğrenme kaygıları arasında orta düzeyde ve negatif yönde anlamlı bir ilişki olduğu sonucuna ulaşılmıştır.

Anahtar Kelimeler: İngilizce Öz Yeterlik İnancı, Öz Yeterlik İnanc1, Lise Öğrencileri, Yabancı Dil Öğrenme Kaygısı.

\title{
An Investigation of High School Students' Self Efficacy Beliefs towards English and their Anxieties about Learning Foreign Language: A Case Study of an Anatolian High School
}

\begin{abstract}
The purpose of this research is to examine high school students' English selfefficacy and foreign language anxiety. Correlational survey model is used in this research. The sample of the study consisted of 686 students, who were selected with easy sampling. The data of the survey were collected through "Personal information sheet", "English self-efficacy scale" and "Foreign language learning anxiety scale". In accordance with the subgoals of the research, descriptive statistics, one-way analysis of independent samples, independent samples t-test, LSD test, Tukey test, Kruskal Wallis-H test, Mann Whitney-U test, and a simple correlation analysis were used in this survey. As a result of the survey, high school students' English self-efficacy significantly differ depending on grade level, family income, participating in an English course, and frequency of study English, whereas no significant difference has been identified in terms of their gender. Besides, high school students' foreign language learning anxiety differ depending on gender, grade level, participating in an English course, and frequency of study English, whereas no significant difference has been identified in terms of their family income. There is a medium-level and negative meaningful correlation between high school students' English self-efficacy and their foreign language learning anxiety.
\end{abstract}

Keywords: English Self-efficacy, Self-Efficacy, High School Students, Foreign Language Learning Anxiety.

\section{GÍRIŞ}

Küreselleşen dünyada ihtiyaç duyulan iletişim becerilerinden biri, ana dilin yanı sıra yabancı bir dili de etkili biçimde kullanabilmektir. Özellikle İngilizceye hem sosyal hem de mesleki açıdan ihtiyaç duyulduğu gibi, akademik çalışmaların ortak bir dil platformunda buluşması da İngilizce ile mümkün olabilmektedir (Ergüder, 2005). Yabancı dili ve özellikle de İngilizceyi öğrenmenin önemi gün geçtikçe artmasına rağmen, yabancı dilin "kime", "nerede" ve "nasıl" öğretileceği ve bu kişilerin özelliklerinin eğitim öncesinde ve sırasında dikkate alınması gerekmektedir (Gökdemir, 2005). Bireyler yabancı bir dili öğrenirken, 
ana dillerine kıyasla o dilin kendilerine karmaşık gelmesinden dolayı zorluk çekebilirler. Ayrıca öğrenilen dilin konuşulduğu ve kullanıldığ öğrenilmesi de durumu daha da zor hale getirebilir (Ünal, 2016). Bu açıdan bakıldığında yabancı dil öğretimi ve öğreniminde dikkate alınması gereken bazı özelliklerden söz etmek mümkündür.

Yabancı dil öğreniminde dikkate alınması gereken özelliklerden biri öz yeterlik algısıdır. Birçok disiplin ve konu alanındaki çalı̧̧maların önemli bir değişkeni olan öz yeterlik kavramı, ilk kez 1977 yılında Bandura tarafindan savunulan sosyal bilişsel kuram ile ortaya çıkmıştır. Öz yeterlik inancı, Bandura tarafından kişilerin zorluklarla karşılaştıkları zaman yapılması gereken eylemi ne kadar çaba göstererek yapabilecekleri ve bu davranışı ne kadar sürdürülebilecekleri hakkında kendilerine ilişkin yargıları şeklinde tanımlanmaktadır (Bandura, 1982, 191-212). Öz yeterlik inanc1, öğrencilerin yabancı dil derslerindeki başarılarına etki etmesinden dolayı öğretim programları hazırlanırken ve eğitim-öğretim etkinlikleri düzenlenirken göz önünde bulundurulması gereken değişkenlerden biridir (Ocak ve Akkaş Baysal, 2016). Bireyin dil becerilerinde kendine ilişkin yetkinlik algısı öz yeterlik inancı ile ilişkilendirilmekte olup, yabancı dil öğrenimine yönelik öz yeterlik inancı bu dille ilgili bilgilerin niceliğinden ziyade, okuma, konuşma, dinleme ve yazma gibi dil becerilerine ilişkin etkinliklerin niteliği ile ilgilidir (Büyükduman, 2006).

Yabanc1 dil öğrenimi sürecinde yaşanan duygulardan bir diğeri de, önemli duyuşsal özelliklerden biri olan kaygıdır. Horwitz, Horwitz ve Cope (1986) yabanc1 dil ile ilgili kaygıy diğer türlerden ayrı bir şekilde yabancı dilin öğrenimine yönelik bir olgu olarak araştıran ilk araştırmacılar arasındadırlar ve bu kaygının kuramsal açıdan çerçevesini oluşturmuşlardır. Yabancı dil kaygısı, dil öğrenimi sırasında karşılaşılan ve kişinin kendini algılamasına yönelik karmaşı inanç, his ve davranışlar olarak belirtilmektedir (Horwitz ve diğerleri, 1986). Konu ile ilgili alanyazın incelendiğinde bazı araştırmacıların (Aida, 1994; Andrade ve Williams, 2009; Foss ve Reitzel, 1988; Horwitz ve diğerleri, 1986; Young, 1990) yabancı dil kaygısını "diğer kaygılardan ayr1, kendine özgü" bir kaygı olarak sınıflandırdıkları görülmektedir. Bu nedenlerden dolayı öğrencilerin kayg1 düzeylerinin belirlenmesinin, bu kaygıların nedenlerinin ortaya çıkarılmasının ve dolayısıyla da bu sebepler ortadan kaldırılarak kaygıdan uzak eğitim öğretim ortamlarının oluşturulmasının yabancı dil eğitimine fayda sağlayacağ

Yabancı dil derslerindeki öz yeterlik algısı ve kaygının ideal düzeylerde bulunması gerekmektedir. Düşük öz yeterlik algısı, yabancı dil öğrenmede performans düşüklügüne yol açabilirken, gereğinden fazla öz yeterlik algısı ise, bazı performanslarda hayal kırıklığına neden olabilir. Benzer şekilde düşük kaygı, yabancı dil öğrenme için gerekli olan içsel dürtülerin az olmasına, çok 
yüksek kayg1 ise öğrenme sürecinde ket vurucu bir etkiye yol açabilir. $\mathrm{Bu}$ nedenle, öğrenme süreçlerinde eğitimcilerin öz yeterlik algısı ve kaygıyı optimal düzeylerde tutacak eğitsel düzenlemeleri yapmaları gerekir.

Alanyazın incelendiğinde öz yeterlik inancı ile ilgili birçok çalışmanın (Alcı ve Yüksel, 2012; Anyadubalu, 2010; Aykol, 2017; Ghonsooly ve Elahi, 2010; Gömleksiz ve Kılınç, 2014; Hancı Yanar, 2008; Hsieh, 2008; Kanadlı ve Bağçeci, 2015; Karanfil ve Arı, 2016; Mills, Pajares ve Herron, 2006; Ocak ve Akkaş Baysal, 2016; Todaka, 2017) yapıldı̆̆ 1 görülmektedir. $\mathrm{Bu}$ çalışmalar incelendiğinde İngilizceye yönelik öz yeterlik inancı ile ilgili çalışmaların daha kısıtlı olduğu görülmektedir. Benzer şekilde, genel olarak kaygi üzerine yapılmış birçok çalışma olmasına rağmen, yabancı dil öğrenme kaygısına ilişkin çalışmaların (Aydoğdu, 2014; Baş, 2014; Batumlu ve Erden, 2007; Burgucu, 2011; Chen ve Chang, 2004; Cui, 2011; Çakıc1, 2015; Çimen, 2011; Çekirdek, 2014; Erkan ve İflazoğlu Saban, 2011; Gülözer, 2010; Hussain, Shahid ve Zaman, 2011; Köse, 2005; Liu ve Chen, 2015; Moore, 2007; Na, 2007; Sarıgül, 2000; Wörde, 2003) sinırlı olduğu görülmektedir.

Bu nedenle araştırmanın, İngilizceye yönelik öz yeterlik inancı ve yabancı dil öğrenme kaygısı değişkenlerini beraberce ele alması açısından ilgili alanyazına katk1 sunacağı düşünülmektedir. Bu bağlamda araştırmanın problem cümlesi "Lise öğrencilerinin İngilizceye yönelik öz yeterlik inançları ile yabancı dil öğrenmeye yönelik kaygılarının çeşitli değişkenlerle ve birbirleri ile olan ilişkileri nasıldır?" şeklinde ifade edilebilir.

\section{Araştırmanın Amacı}

Bu çalışmanın genel amacı, lise öğrencilerinin İngilizceye yönelik öz yeterlik inançlarını ve yabancı dil öğrenmeye yönelik kaygılarını incelemektir. Bu genel amaç doğrultusunda aşağıdaki sorulara yanıt aranmıştır:

1. Lise öğrencilerinin İngilizceye yönelik öz yeterlik inançları; cinsiyetlerine, sınıflarına, ailelerinin maddi gelirlerine, yabancı dil kursuna gidip gitmeme durumuna ve İngilizce öğrenmeye ayırdıkları zamana göre anlamlı farklılık göstermekte midir?

2. Lise öğrencilerinin yabancı dil öğrenmeye yönelik kaygıları; cinsiyetlerine, sinıflarına, ailelerinin maddi gelirlerine, yabancı dil kursuna gidip gitmeme durumuna ve İngilizce öğrenmeye ayırdıkları zamana göre anlamlı farklılık göstermekte midir?

3. Lise öğrencilerinin İngilizceye yönelik öz yeterlik inançları ile yabancı dil öğrenmeye yönelik kaygıları arasında anlamlı bir ilişki bulunmakta mıdır? 


\section{YÖNTEM}

Araştırmanın bu bölümünde araştırmanın modeli, evren ve örneklemi, veri toplama araçları, verilerin toplanması ve verilerin analizi ile bilgiler yer almaktadır.

\section{Araştırmanın Modeli}

Araştırma betimsel tarama modellerinden olan ilişkisel tarama modelinde tasarlanmıştır. İliş̧isel tarama modelleri, iki ya da daha çok değişkenin arasında olan birlikte değişimin varlığını ya da derecesini ortaya koymayı hedefleyen bir araştırma modelidir (Karasar, 2009). Bu çalışmanın bağımlı değişkenleri İngilizce ile ilgili öz yeterlik inancı ve yabancı dil öğrenme kaygısı iken; bağımsız değişkenleri lise öğrencilerinin cinsiyetleri, sınıf düzeyleri, ailelerinin maddi gelirler düzeyleri, İngilizceye yönelik kursa gidip gitmeme durumları ve İngilizce dersine çalışma sıklıklarıdır. Araştırmada var olan bir durum ortaya konulmaya ve değişkenlerin birbirleriyle olan ilişki düzeyleri belirlenmeye çalışılmıştır.

\section{Evren ve Örneklem}

Çalışmanın evrenini 2019-2020 eğitim-öğretim yılında Gaziantep'in Şahinbey ilçesindeki bir Anadolu lisesinin 9, 10, 11 ve 12. sınıflarında öğrenim görmekte olan 1118 öğrenci oluşturmaktadır. $\% 95$ olasılık ve $\% 5$ hata oranı ile bu evrende en az 286 öğrenciye ulaşılması gerektiği hesaplanmıştır. Buna göre, çalışmanın örneklemini oluşturan ve bu evrenden amaçlı örnekleme yöntemlerinden olan kolay ulaş1labilir durum örneklemesiyle seçilen 686 öğrencinin evreni temsil etme gücünde olduğu görülmektedir. Kolay ulaşılabilir örnekleme yöntemi araştırma yapan kişiye hız ve pratiklik kazandırır. Çünkü bu yöntem ile araştırmacı, kendine yakın olan ve erişmesi kolay bir durumu tercih eder (Yıldırım ve Şimşek, 2016). Çalışmanın verileri araştırmacılardan birinin görev yaptığı okulda toplandığından dolayı örneklemin kolay ulaşılabilir örneklemeye uygun olduğu düşünülmektedir. Bu çalışmanın Kahramanmaraş Sütçü İmam Üniversitesi Sosyal ve Beşeri Bilimler Etik Kurulu'ndan alınan 22.04.2020 tarih ve E. 16857 sayılı etik kurul izni mevcuttur.

\section{Veri Toplama Araçları}

Araştırmada veri toplama aracı olarak; "Kişisel Bilgi Formu”, "İngilizce İle İlgili Öz yeterlik İnancı Ölçeği" ve "Yabanc1 Dil Öğrenme Kaygısı Ölçeği”" kullanılmıştır. 


\section{Kişisel Bilgi Formu}

Araştırmacılar tarafından hazırlanan kişisel bilgi formu, lise öğrencilerinin cinsiyet, sınıf, ailenin maddi geliri, İngilizceye yönelik kursa gidip gitmeme durumları ve İngilizce dersine ayırdıkları zaman gibi bazı demografik özelliklerine ilişkin bilgileri kapsamaktadır.

\section{İngilizce ile İlgili Öz Yeterlik İnancı Ölçeği}

Lise öğrencilerinin İngilizceye yönelik öz yeterlik inançlarını belirleyebilmek amacıyla öğrencilere İngilizce ile ilgili Öz Yeterlik İnancı Ölçeği (İİÖYIIÖ) uygulanmıştır. Öğrencilere uygulanan İïÖYYİ̈ Hancı Yanar ve Bümen (2012) tarafindan geliştirilmiştir. Ölçek "okuma", "yazma", "dinleme" ve "konuşma" olmak üzere 4 alt boyuttan ve 33 maddeden oluşmaktadır. Ölçek beşli Likert tipinde olup "1=Bana hiç uymuyor, 2=Çok az uyuyor, $3=$ Biraz uyuyor, 4=Oldukça uyuyor, 5=Bana tamamen uyuyor" seçeneklerinden oluşmaktadır. Ölçekten alınabilecek en düşük puan 33, en yüksek puan ise $165^{\prime}$ tir. Puanların 33'e yaklaşması öz yeterlik inancının düştüğünü, 165'e yaklaşması öz yeterlik inancının yükseldiğini göstermektedir. Ölçeğin güvenirliğinin belirlenmesi için Cronbach Alpha katsayısı hesaplanmıştır. Ölçeğin tümü için elde edilen Cronbach alpha katsayısı .97 'dir. Bu değerler okuma boyutu için .92, yazma boyutu için .88 , dinleme boyutu için .93 ve konuşma boyutu için .92 olarak bulunmuştur (Hancı Yanar ve Bümen, 2012). Bu araştırmadan elde edilen verilerle yeniden hesaplanan güvenirlik katsayısı ölçeğin tamamı için .96'dır. Okuma, yazma, dinleme ve konuşma alt boyutları için hesaplanan güvenirlik katsayıları ise sırasıyla $.87, .85, .90$ ve .89 şeklindedir.

\section{Yabancı Dil Öğrenme Kaygısı Ölçeği}

Lise öğrencilerinin yabancı dil öğrenmeye yönelik kaygılarını belirleyebilmek amaciyla öğrencilere yabanc1 dil öğrenme kaygisı ölçeği (YDÖKÖ) uygulanmıştır. Ölçek Baş (2013) tarafından geliştirilmiş olup, "kişilik", "iletişim" ve "değerlendirme" olmak üzere üç alt boyuttan ve 27 maddeden oluşmaktadır. Ölçek beşli Likert tipinde olup " $1=$ Kesinlikle Katılmıyorum, 2=Katılmıorum, 3=Kararsızım, 4=Katıliyorum, 5=Kesinlikle Katıliyorum” seçeneklerinden oluşmaktadır. Ölçekten alınabilecek en düşük puan 27 , en yüksek puan ise 135 'tir. Puanların 27'ye yaklaşması yabancı dil öğrenme kaygısının düştüğünü, 135'e yaklaşması yabancı dil öğrenme kaygısının yükseldiğini göstermektedir. Ölçeğin güvenirliğinin ortaya konulabilmesi için Cronbach Alpha Katsayısı hesaplanmıştır. Ölçeğin tümü için Cronbach alpha katsayısı .93 'tür. $\mathrm{Bu}$ değerler Kişilik boyutu için .89 , İletişim boyutu için . 88 , Değerlendirme boyutu için de .83 olarak bulunmuştur (Baş, 2013). YDÖKÖ'nün geçerlik ve güvenirlik çalışmalarından elde edilen sonuçlar, ölçeğin güvenle kullanılabileceğine işaret etmektedir. $\mathrm{Bu}$ araştırmadan elde edilen verilerle 
yeniden hesaplanan güvenirlik katsayısı ölçeğin tamamı için .87 'dir. Kişilik, iletişim ve değerlendirme alt boyutları için hesaplanan güvenirlik katsayıları ise sırasıyla $.63, .77$ ve .73 şeklindedir. Ölçeğin kişilik alt boyutunun güvenirlik katsayısının .63 olarak bulunmasının, verinin tek bir okuldan toplanmasından dolayı örneklemin homojen yapısından kaynaklandığı düşünülmektedir.

\section{Verilerin Toplanması ve Analizi}

Araştırmanın verileri 2019-2020 eğitim-öğretim y1lında Gaziantep ilinin Şahinbey ilçesinde bulunan bir lisede öğrenim gören öğrencilerden toplanmıştır. Veri toplama araçları öğrencilere bulundukları okulda verilmiş ve veri toplama araçlarıyla ilgili gerekli açıklamalar yapıldıktan sonra doldurulması sağlanmıştır. Cevap kâğıtlarından eksik veya birden fazla işaretlenmiş seçenek olduğu tespit edilenler geçersiz sayılmış ve değerlendirmeye alınmamıştır.

Verilerin istatistiksel çözümlemelerinin yapılabilmesi amacıyla bilgisayar paket programına girişleri yapılmıştır. Ayrıca, grupların varyanslarının homojen olup olmadığını tespit etmek amacıyla Levene's testi yapılmıştır. Böylece lise öğrencilerinin İngilizce ile ilgili öz yeterlik algıları ile yabancı dil öğrenme kaygılarının çeşitli demografik değişkenlere (cinsiyet ve herhangi bir İngilizce kursuna katılma durumu) göre farklılaşıp farklılaşmadığının belirlenmesinde bağımsız gruplar t-testi uygulanmıştır. Lise öğrencilerinin İngilizce ile ilgili öz yeterlik algıları ile yabancı dil öğrenme kaygılarının diğer değişkenlere (sınıf düzeyi, aile gelir düzeyi ve İngilizce dersine çalışma sıklığı) göre farklılaşıp farklılaşmadığının belirlenmesi için ise tek yönlü varyans analizi (ANOVA) uygulanmıştır. Anlamlı farklılaşmanın tespit edildiği durumlarda bu farklılığın hangi gruplar arasında olduğunu belirlemek amaciyla Tukey ve LSD anlamlılık çözümlemesi yapılmıştır. Varyansların homojen dağılmadığı durumlarda ise Kruskal Wallis-H testi uygulanmış, bu test sonucunda tespit edilen farklılaşmanın hangi gruplar arasında olduğunu belirlemek amaciyla da Mann Whitney U testi kullanılmıştır. Elde edilen toplam puanların İngilizce ile ilgili öz yeterlik algısı ve yabancı dil öğrenme kaygısı ölçeğinin alt boyutlarının madde sayısına bölünmesi ile 5 puan üzerinden aritmetik ortalamaları belirlenmiştir. Son olarak öğrencilerinin İngilizce ile ilgili öz yeterlik algıları ile yabancı dil öğrenme kaygıları arasındaki ilişkinin tespit edilmesi için Pearson Korelasyon analizi kullanılmıştır. Korelasyon değerleri yorumlanırken, 0-.30 arası düşük, .31-.70 aras1 orta, .71-1 aras1 yüksek korelasyon (Büyüköztürk, 2018) olarak değerlendirilmiştir. Anlamlı farkların tespit edildiği testlerde, bağımsız değişkenin bağımlı değişken üzerindeki etkisinin büyüklüğünün hesaplanması için eta-kare ( $\eta 2)$ ve Cohen d etki büyüklüğü istatistikleri kullanılmıştır. Eta-kare .00 ve 1.00 arasında değer alır ve $.01, .06$ ve .14 . düzeyindeki değerler, aynı sıra ile "küçük", "orta" ve "geniş" etki büyüklüğü olarak yorumlanır (Büyüköztürk, 2018). Cohen'in etki büyüklüğü değeri; .20-.50 arasında olduğunda "küçük", .50- 
.80 arasında olduğunda "orta", .80 ve üzerinde ise "geniş" olarak yorumlanır (Cohen, 1988).

\section{BULGULAR}

Araştırmanın bu bölümünde araştırmaya katılan lise öğrencilerinin İngilizceye yönelik öz yeterlik inançlarına ve yabancı dil öğrenmeye yönelik kaygılarına ilişkin bulgulara yer verilmiştir.

\section{Lise Öğrencilerinin İngilizce ile İlgili Öz Yeterlik İnançlarının İncelenmesine İlişkin Bulgular}

Lise öğrencilerinin İİIÖYİÖ’den aldıkları puanlara ilişkin betimsel istatistikler Tablo 1'de sunulmuştur.

Tablo 1. Lise Öğrencilerinin İngilizce ile ilgili Öz Yeterlik İnançlarına İlişkin Betimsel İstatistikler

\begin{tabular}{llll}
\hline Alt Boyutlar/ Ölçeğin Tamamı & $\boldsymbol{N}$ & $\overline{\boldsymbol{X}}$ & ss \\
\hline Okuma & 686 & 2.86 & .86 \\
Yazma & 686 & 2.55 & .81 \\
Dinleme & 686 & 2.68 & .87 \\
Konuşma & 686 & 2.55 & .96 \\
İİÖȮंÖ & 686 & 2.66 & .79 \\
\hline
\end{tabular}

Tablo 1 incelendiğinde, lise öğrencilerinin İİIÖYİÖ'den aldıkları toplam puanların ortalaması 2.66 olarak hesaplanmıştır. Ölçek alt boyutlarından alınan toplam puanların aritmetik ortalamalarının ise 2.55 ila 2.86 puanları arasında değiştiği görülmektedir. Her bir alt boyuttan alınabilecek en yüksek ortalama puanın 5 olduğu dikkate alındığında, lise öğrencilerinin İngilizce ile ilgili öz yeterlik algılarının alt boyutların tamamında ortalamanın üzerinde olduğu ifade edilebilir.

Lise öğrencilerinin İngilizce ile ilgili öz yeterlik inançlarının cinsiyet değişkenine göre anlamlı farklılaşıp farklılaşmadığını belirlemek için yapılan bağımsız gruplar t-testinin sonuçları Tablo 2'de sunulmuştur.

Tablo 2. Lise Öğrencilerinin İngilizce ile İlgili Öz Yeterlik İnançlarının Cinsiyete Göre Bağımsız Gruplar t-testi Sonuçları

\begin{tabular}{|c|c|c|c|c|c|c|c|}
\hline Boyut & Cinsiyet & $N$ & $\overline{\boldsymbol{X}}$ & Ss & $s d$ & $t$ & $p$ \\
\hline İİİÖYİÖ & $\begin{array}{l}\text { Kadın } \\
\text { Erkek }\end{array}$ & $\begin{array}{l}343 \\
342\end{array}$ & $\begin{array}{l}2.60 \\
2.72\end{array}$ & $\begin{array}{l}.82 \\
.76\end{array}$ & 683 & -1.947 & .052 \\
\hline
\end{tabular}


Tablo 2 incelendiğinde, lise öğrencilerinin İi̇ÖYIÖ’nün tamamına ait puanları arasında erkek öğrencilerin lehine anlamlı farklılık bulunmamaktadır, $\mathrm{t}(683)=-1.947, \mathrm{p}>.05$.

İİÖYIÖ'nün tamamına ait puan dağılımlarının varyanslarının homojen olmadığı görüldüğ̈̈nden (Levene $\mathrm{F}=15.611, \mathrm{p}<.05$ ), lise öğrencilerinin İngilizce ile ilgili öz yeterlik inançlarının sınıf düzeyine göre anlamlı olarak farklılaşıp farklılaşmadığını belirlemek için yapılan Kruskal Wallis-H testi sonuçları Tablo 3'te verilmiştir.

Tablo 3. Lise Öğrencilerinin İngilizce ile İlgili Öz Yeterlik İnançlarının Sınıf Düzeyine Göre Kruskal Wallis-H Testi Sonuçları

\begin{tabular}{lllllll}
\hline & Sinif & & & & \\
Ölçek & Düzeyi & $\boldsymbol{N}$ & $\boldsymbol{S . O}$ & $\boldsymbol{s} \boldsymbol{d}$ & $\boldsymbol{X}^{2}$ & $\boldsymbol{p}$ \\
\hline İİ̈ÖYİÖ & 9 & 223 & 403.92 & 3 & 45.47 & $.000^{*}$ \\
& 10 & 179 & 358.61 & & & \\
& 11 & 142 & 280.87 & & & \\
\hline
\end{tabular}

$* \mathrm{p}<.05$

Tablo 3'te görüldüğ̈̈ gibi, lise öğrencilerinin IIIİÖYİÖ puanları arasında sınıf düzeyine göre anlamlı fark bulunmuştur, $\mathrm{X}^{2}=45.47, \mathrm{p}<.05$. Farkın hangi gruplar arasında olduğunu belirlemek amacıyla yapılan Mann Whitney-U testi sonuçları incelendiğinde, lise öğrencilerinin İngilizce ile ilgili öz yeterlik inançları puanları 9 ve 10. sinıflar arasında 9. sinıflar lehine anlamlı farklılık olduğu görülmektedir, $\mathrm{U}=17140.500, \mathrm{p}<.05$. Farklı siniflar arasinda hesaplanan Cohen $\mathrm{d}$ etki büyüklükleri .12 ila .30 arasında değiştiğinden, İîiöYíÖ’nün tamamında gözlenen varyansın $\% 12$ ila $\% 30$ oranında sınıf düzeyine bağlı olduğu düşünülebilir. Dolayısıyla, sınıf düzeyi İi̇ÖYYIÖ’nün tamamına ait puanları düşük düzeyde etkilemektedir.

Lise öğrencilerinin İngilizce ile ilgili öz yeterlik inançlarının aile gelirine göre anlamlı olarak farklılaşıp farklılaşmadığını belirlemek için yapılan ANOVA sonuçları Tablo 4'te verilmiştir.

Tablo 4 incelendiğinde, lise öğrencilerinin İİÖYIÖ puanlarının aile gelirine göre anlamlı şekilde farklılaştığ 1 görülmektedir, $\mathrm{F}(4,663)=3.505, \mathrm{p}<.05$. Farkın kaynağını bulmak için yapılan LSD testi sonucunda, aile gelirleri 0-2000 TL arasında olan ve $5001 \mathrm{TL}$ ve üzeri olan öğrenciler arasında maddi gelirleri 5001 TL ve üzeri olan öğrenciler lehine; aile gelirleri 2001-3000 TL arasında olan ve $5001 \mathrm{TL}$ ve üzeri olan öğrenciler arasında aile gelirleri $5001 \mathrm{TL}$ ve üzeri olan öğrenciler lehine; aile gelirleri 3001-4000 TL arasında olan ve 5001 TL ve üzeri olan öğrenciler arasında aile gelirleri $5001 \mathrm{TL}$ ve üzeri olan öğrenciler lehine; 
aile gelirleri 4001-5000 TL arasında olan ve 5001 TL ve üzeri olan öğrenciler arasında aile gelirleri $5001 \mathrm{TL}$ ve üzeri olan öğrenciler lehine anlamlı fark bulunmuştur.

Tablo 4. Lise Öğrencilerinin İngilizce ile İlgili Öz Yeterlik İnançlarına İlişkin Puanların Ailelerin Maddi Gelirine Göre ANOVA Sonuçları

\begin{tabular}{|c|c|c|c|c|c|c|c|c|c|c|c|}
\hline Ölçek & Maddi Gelir & $N$ & $\overline{\boldsymbol{X}}$ & Ss & $V K$ & K.T & $s d$ & K.O & $\boldsymbol{F}$ & $p$ & $\eta^{2}$ \\
\hline \multirow{6}{*}{$\begin{array}{l}: 0 \\
: 0 \\
: \vdots\end{array}$} & 1)0-2000 TL & 123 & 2.61 & .87420 & G.A. & 8.721 & 4 & 2.180 & \multirow[t]{6}{*}{3.505} & $.008^{*}$ & \multirow[t]{6}{*}{.02} \\
\hline & 2)2001-3000 TL & 210 & 2.64 & .77853 & G.İ. & 412.384 & 663 & \multirow[t]{5}{*}{.622} & & Fark & \\
\hline & 3)3001-4000 TL & 162 & 2.64 & .74025 & \multirow[t]{4}{*}{ Top. } & \multirow[t]{4}{*}{421.104} & \multirow[t]{4}{*}{667} & & & $5>1$ & \\
\hline & 4)4001-5000 TL & 78 & 2.62 & .75114 & & & & & & $5>2$ & \\
\hline & 5)5001 TL ve üzeri & 95 & 2.96 & .80428 & & & & & & $5>3$ & \\
\hline & Toplam & 668 & 2.68 & .79457 & & & & & & $5>4$ & \\
\hline
\end{tabular}

$* \mathrm{p}<.05$

Lise öğrencilerinin İngilizce ile ilgili öz yeterlik inançlarının kursa katılma değişkenine göre anlamlı farklılaşıp farklılaşmadığını belirlemek için yapılan bağımsız gruplar t-testinin sonuçları Tablo 5'te verilmiştir.

Tablo 5. Lise Öğrencilerinin İngilizce ile İlgili Öz Yeterlik İnançlarının Kursa Katılma Durumuna Göre Bağımsız Gruplar t-testi Sonuçları

\begin{tabular}{|c|c|c|c|c|c|c|c|c|}
\hline Ölçek & $\begin{array}{l}\text { Kursa } \\
\text { Katılma }\end{array}$ & $N$ & $\overline{\boldsymbol{X}}$ & sS & $s d$ & $t$ & $p$ & $\eta^{2}$ \\
\hline İİÏÖYİÖ & $\begin{array}{l}\text { Evet } \\
\text { Hayır }\end{array}$ & $\begin{array}{l}132 \\
548\end{array}$ & $\begin{array}{l}3.19 \\
2.53\end{array}$ & $\begin{array}{l}.75 \\
.74\end{array}$ & 678 & 9.147 & $.000 *$ & .11 \\
\hline
\end{tabular}

$* \mathrm{p}<.05$

Tablo 5'te görüldüğü üzere, öğrencilerin İî̇ÖYİÖ puanları arasında İngilizce kursuna katılan öğrenciler lehine anlamlı fark olduğu belirlenmiştir, $\mathrm{t}(678)=9.147, \mathrm{p}<.05$. Etki büyüklükleri dikkate alındığında, ölçekte gözlenen varyansın \%11 oranında İngilizce kursuna katılma durumuna bağlı olduğu düşünülebilir. Dolayısıyla, İngilizce kursuna katılma durumunun İngilizce ile ilgili öz yeterlik algısını orta düzeyde etkilediği belirtilebilir.

İi̇ÖYİ̈’nün tamamına ait puan dağılımı varyanslarının homojen olmadığı görüldüğünden (Levene $\mathrm{F}=5.043, \mathrm{p}<.05$ ), lise öğrencilerinin İngilizce ile ilgili öz yeterlik inançlarının ders çalışma sıklığ farklılaşmadığını belirlemek için yapılan Kruskal Wallis-H testi sonuçları Tablo 6'da verilmiştir. 
Tablo 6. Lise Öğrencilerinin İngilizce ile ilgili Öz Yeterlik İnançlarının Ders Çalışma Sıklığına Göre Kruskal Wallis-H Testi Sonuçları

\begin{tabular}{|c|c|c|c|c|c|c|}
\hline Ölçek & $\begin{array}{c}\text { Ders } \\
\text { Çalışma Sıklığı }\end{array}$ & $N$ & S.O & $s d$ & $X^{2}$ & $p$ \\
\hline \multirow[t]{5}{*}{ İiIIÖYİÖ } & Her gün & 59 & 547.81 & 4 & 150.643 & $.000 *$ \\
\hline & Haftada bir & 329 & 386.49 & & & \\
\hline & Ayda bir & 92 & 285.92 & & & \\
\hline & Birkaç ayda bir & 79 & 279.25 & & & \\
\hline & Hiç çalışmıyorum & 125 & 211.44 & & & \\
\hline
\end{tabular}

$* \mathrm{p}<.05$

Tablo 6' da görüldüğü gibi, lise öğrencilerinin İi̇ÖYYIÖ puanları arasında ders çalışma sıklığına göre anlamlı fark bulunmuştur, $\mathrm{X}^{2}=150.643, \mathrm{p}<.05$. Anlamlı farklılığın hangi gruplar arasında olduğunun belirlenmesi için yapılan Mann Whitney-U testi sonucuna göre lise öğrencilerinin İngilizce ile ilgili öz yeterlik inancı puanları arasında her gün ders çalışanlar ile haftada bir çalışanlar arasında her gün çalışanlar lehine ( $\mathrm{U}=4316.500)$; her gün ders çalışanlar ile ayda bir çalışanlar arasında her gün çalışanlar lehine $(\mathrm{U}=667.000)$; her gün ders çalışanlar ile birkaç ayda bir çalışanlar arasında her gün çalışanlar lehine $(U=496.000)$; her gün ders çalışanlar ile hiç çalışmayanlar arasında her gün çalışanlar lehine $(\mathrm{U}=844.500)$; haftada bir ders çalışanlar ile ayda bir çalışanlar arasında haftada bir çalışanlar lehine ( $\mathrm{U}=10227.000)$; haftada bir ders çalışanlar ile birkaç ayda bir çalışanlar arasında haftada bir çalışanlar lehine (U=8427.500); haftada bir ders çalışanlar ile hiç çalışmayanlar arasında haftada bir çalışanlar lehine ( $\mathrm{U}=10177.000)$; ayda bir ders çalışanlar ile hiç çalışmayanlar arasında ayda bir çalışanlar lehine $(\mathrm{U}=4065.000)$ ve birkaç ayda bir ders çalışanlar ile hiç çalışmayanlar arasında birkaç ayda bir çalışanlar lehine $(\mathrm{U}=3468.000)$ anlamlı fark bulunmuştur $(\mathrm{p}<.05)$. Farklı çalışma süreleri arasında hesaplanan eta-kare sonuçları .23 ila .67 arasında değiştiğinden, ölçeğin tamamında gözlenen varyansın \%23 ila \%67 oranında ders çalışma sıklığına bağlı olduğu düşünülebilir. Dolayısıyla, ders çalışma sıklığının İi̇ÖÖYIOO’nün tamamın ait puanları düşük düzeyde etkilediği belirtilebilir.

\section{Lise Öğrencilerinin Yabancı Dil Öğrenme Kaygılarının İncelenmesine İlişkin Bulgular}

Lise öğrencilerinin YDÖKÖ'den aldıkları puanlara ilişkin betimsel istatistikler Tablo 7'de sunulmuştur. 
Tablo 7. Lise Öğrencilerinin Yabancı Dil Öğrenme Kaygılarına İlişkin Betimsel İstatistikler

\begin{tabular}{lccc}
\hline $\begin{array}{l}\text { Alt Boyutlar/ } \\
\text { Ölçeğin Tamamı }\end{array}$ & $\boldsymbol{N}$ & $\overline{\boldsymbol{X}}$ & ss \\
\hline Kişilik & 686 & 2.84 & .69 \\
İletişim & 686 & 2.94 & .76 \\
Değerlendirme & 686 & 3.18 & .83 \\
YDÖKÖ & 686 & 2.98 & .66 \\
\hline
\end{tabular}

Tablo 7'de görüldüğü üzere lise öğrencilerinin YDÖKÖ’den aldıkları toplam puanların ortalaması 2.98 şeklinde hesaplanmıştır. Ölçek alt boyutlarından alınan toplam puanların aritmetik ortalamalarının ise 2.84 ila 3.18 puanları arasında değiştiği görülmektedir. Her bir alt boyuttan alınabilecek en yüksek ortalama puanın 5 olduğu dikkate alındığında, lise öğrencilerinin yabancı dil öğrenme kaygilarının alt boyutların tamamında ortalamanın üzerinde olduğu ifade edilebilir.

YDÖKÖ'nün tamamına ait puan dağılımlarındaki varyansların homojen olmadığı görüldüğünden (Levene $\mathrm{F}=9.541, \mathrm{p}<.05$ ), lise öğrencilerinin yabancı dil öğrenme kaygılarının cinsiyet değişkenine göre anlamlı farklılaşıp farklılaşmadığını belirlemek için yapılan Mann Whitney-U testi sonuçları Tablo 8 'de verilmiştir.

Tablo 8. Lise Öğrencilerinin Yabancı Dil Öğrenme Kaygılarının Cinsiyete Göre Mann Whitney-U Testi Sonuçları

\begin{tabular}{lllllllc}
\hline Ölçek & Cinsiyet & $\boldsymbol{N}$ & $\boldsymbol{S} . \boldsymbol{O}$ & $\boldsymbol{S} . \boldsymbol{T}$ & $\boldsymbol{U}$ & $\boldsymbol{p}$ & Cohen d \\
\hline \multirow{3}{*}{ YDÖKÖ } & Kadın & 343 & 359.78 & 123404.50 & & & \\
& Erkek & 342 & 326.17 & 111550.50 & 52897.5 & $.026^{*}$ & .08 \\
\hline
\end{tabular}

$* \mathrm{p}<.05$

Tablo 8'de görüldüğü gibi lise öğrencilerinin YDÖKÖ puanları arasında cinsiyet değişkenine göre anlamlı farklılık tespit edilmiştir, $U=52897.5, \mathrm{p}<.05$. Ölçeğin tamamına ait sıra ortalamaları dikkate alındığında, kadın öğrencilerin yabancı dil öğrenme kaygılarının erkek öğrencilerden anlamlı bir şekilde yüksek olduğu görülmektedir. Etki büyüklüğü dikkate alındığında, ölçeğin tamamında gözlenen varyansın $\% 8$ oranında cinsiyete bağlı olduğu düşünülebilir. Dolayısıyla, cinsiyetin YDÖKÖ'nün tamamına ait puanları düşük düzeyde etkilediği belirtilebilir. 
YDÖKÖ'nün tamamına ait puan dağılımlarındaki varyansların homojen olmadığı görüldügünden (Levene $\mathrm{F}=5.362, \mathrm{p}<.05$ ), lise öğrencilerinin yabanc1 dil öğrenme kaygıları puanlarının sınıf düzeyine göre anlamlı olarak farklılaşıp farklılaşmadığını belirlemek için yapılan Kruskal Wallis-H testi sonuçları Tablo 9'da verilmiştir.

Tablo 9. Lise Öğrencilerinin Yabancı Dil Öğrenme Kaygılarının Sınıf Düzeyine Göre Kruskal Wallis-H Testi Sonuçları

\begin{tabular}{lllllll}
\hline Ölçek & Sinıf Düzeyi & $\boldsymbol{N}$ & S.O & sd & $\boldsymbol{X}^{2}$ & $\boldsymbol{p}$ \\
\hline YDÖKÖ & 9 & 223 & 320.27 & 3 & 33.256 & $.000^{*}$ \\
& 10 & 179 & 374.40 & & & \\
& 11 & 142 & 402.02 & & & \\
& 12 & 142 & 282.51 & & & \\
\hline *p<.05 & & & &
\end{tabular}

$* \mathrm{p}<.05$

Tablo 9'da görüldüğü gibi, lise öğrencilerinin YDÖKÖ puanları arasında sınıf düzeyine göre anlamlı fark bulunmuştur, $\mathrm{X}^{2}=33.256, \mathrm{p}<.05$. Anlamlı farklılığın hangi gruplar arasında olduğunun belirlenmesi için yapılan Mann Whitney-U testine ilişkin sonucuna göre lise öğrencilerinin yabancı dil öğrenme kaygısı puanlarında 9 ve 10. siniflar arasinda 10. siniflar lehine (U=16826.000), 9 ve 11. sinıflar arasinda 11. siniflar lehine ( $U=12184.000), 10$ ve 12. siniflar arasinda 10. siniflar lehine $(\mathrm{U}=9199.000)$ ve 11 ve 12 . siniflar arasinda 11. siniflar lehine $(\mathrm{U}=6532.500)$ anlamlı farklılık olduğu görülmektedir $(\mathrm{p}<.05)$. Farklı sinıf düzeyleri arasında hesaplanan Cohen $\mathrm{d}$ değerleri .13 ila .30 arasında değiştiğinden, ölçeğin tamamında gözlenen varyansın \%13 ila \%30 oranında sınıf düzeyine bağlı olduğu düşünülebilir. Dolayısıyla, sınıf düzeyinin YDÖKÖ’nün tamamına ait puanları düşük düzeyde etkilediği belirtilebilir.

YDÖKÖ'nün tamamına ait puan dağılımlarındaki varyansların homojen olmadığı görüldügünden (Levene $\mathrm{F}=6.136, \mathrm{p}<.05$ ), lise öğrencilerinin yabanc1 dil öğrenme kaygıları puanlarının aile gelir düzeyine göre anlamlı olarak farklılaşıp farklılaşmadığını belirlemek için yapılan Kruskal Wallis-H testi sonuçları Tablo 10'da verilmiştir. 
Tablo 10. Lise Öğrencilerinin Yabancı Dil Öğrenme Kaygılarının Aile Gelirine Göre Kruskal Wallis-H Testi Sonuçları

\begin{tabular}{lllllll}
\hline Ölçek & Maddi Gelir & $\boldsymbol{N}$ & S.O & sd & $\boldsymbol{X}^{\mathbf{2}}$ & $\boldsymbol{p}$ \\
\hline YDÖKÖ & 0-2000 TL & 123 & 352.38 & 4 & 2.608 & .625 \\
& 2001-3000 TL & 210 & 329.55 & & & \\
& 3001-4000 TL & 162 & 342.12 & & & \\
& 4001-5000 TL & 78 & 329.10 & & & \\
& 5001 TL ve üzeri & 95 & 313.74 & & & \\
\hline
\end{tabular}

Tablo 10'da görüldüğü gibi lise öğrencilerinin YDÖKÖ puanları arasında aile gelirine göre anlamlı farklılık göstermemektedir, $X^{2}=2.608, p>.05$.

Lise öğrencilerinin yabancı dil öğrenme kaygılarının kursa katılma değişkenine göre anlamlı olarak farklılaşıp farklılaşmadığını belirlemek için yapılan bağımsız gruplar t-testinin sonuçları Tablo 11'de verilmiştir.

Tablo 11'de görüldüğü gibi, YDÖKÖ puanları arasında İngilizce kursuna katılmayan öğrenciler lehine anlamlı fark olduğu belirlenmiştir, $\mathrm{t}(678)=-4.535$, $\mathrm{p}<.05$. Etki büyüklüğü dikkate alındığında, ölçekte gözlenen varyansın $\% 2$ oranında kursa katılma durumuna bağlı olduğu düşünülebilir. Dolayısıyla, kursa katılma durumunun YDÖKÖ puanlarının tamamını düşük düzeyde etkilediği belirtilebilir.

Tablo 11. Lise Öğrencilerinin Yabancı Dil Öğrenme Kaygılarının Kursa Katılma Durumuna Göre Bağımsız Gruplar t-testi Sonuçları

\begin{tabular}{|c|c|c|c|c|c|c|c|c|}
\hline Ölçek & $\begin{array}{l}\text { Kursa } \\
\text { Katılma }\end{array}$ & $N$ & $\overline{\boldsymbol{X}}$ & $S S$ & $s d$ & $t$ & $p$ & $\eta^{2}$ \\
\hline \multirow{2}{*}{ YDÖKÖ } & Evet & 132 & 2.75 & .69 & \multirow[t]{2}{*}{678} & \multirow[t]{2}{*}{-4.535} & \multirow[t]{2}{*}{$.000 *$} & \multirow[t]{2}{*}{.02} \\
\hline & Hayır & 548 & 3.04 & .64 & & & & \\
\hline
\end{tabular}

$* \mathrm{p}<.05$

Lise öğrencilerinin yabancı dil öğrenme kaygıları puanlarının ders çalışma sıklığına göre anlamlı olarak farklılaşıp farklılaşmadığını belirlemek için yapılan ANOVA sonuçları Tablo 12'de verilmiştir. 
Tablo 12. Lise Öğrencilerinin Yabancı Dil Öğrenme Kaygılarına İlişkin Puanların Ders Çalışma Sıklığına Göre ANOVA Sonuçları

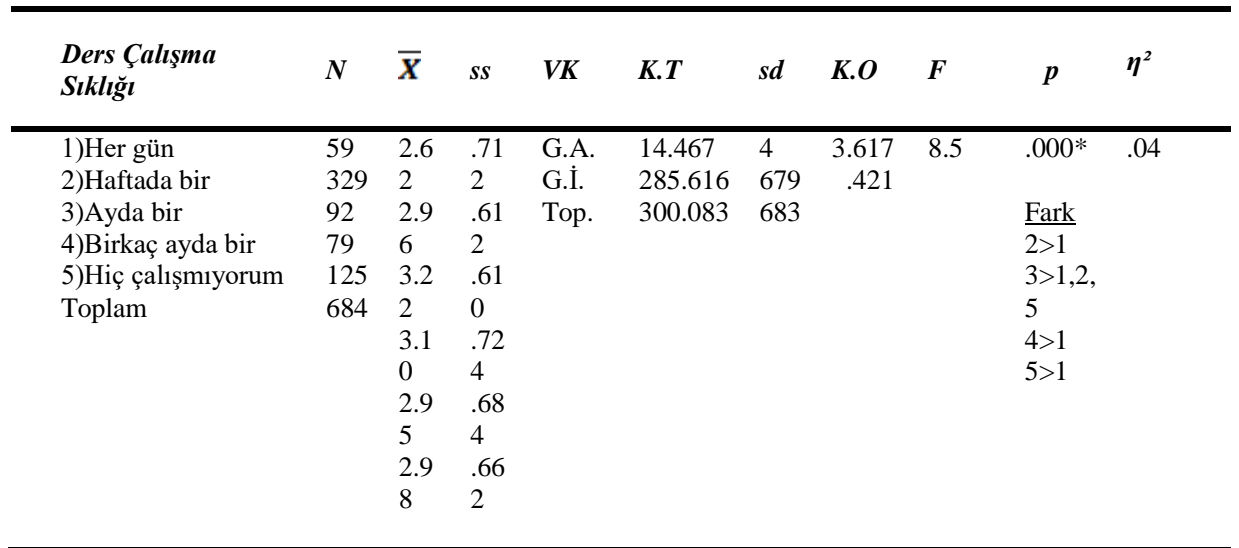

$* \mathrm{p}<.05$

Tablo 12 incelendiğinde, lise öğrencilerinin YDÖKÖ puanlarının ders çalışma sıklığına göre anlamlı şekilde farklılaştı̆ 1 görülmektedir, $F(4,679)=3.617$, p< .05. Farkın kaynağını bulmak için yapılan post-hoc tekniklerinden Tukey testi sonucunda haftada bir ders çalışanlar ile her gün çalışanlar arasında haftada bir ders çalışanlar lehine; ayda bir ders çalışanlar ile her gün çalışanlar, haftada bir çalışanlar ve hiç çalışmayanlar arasında ayda bir çalışanlar lehine; birkaç ayda bir çalışanlar ile her gün çalışanlar arasında birkaç ayda bir çalışanlar lehine ve hiç çalışmayanlar ile her gün çalışanlar arasında hiç çalışmayanlar lehine anlamlı farklılık bulunmuştur. Etki büyüklüğü dikkate alındığında, ölçeğin tamamında gözlenen varyansın \%4 oranında ders çalışma sıklığına bağlı olduğu düşünülebilir. Dolayısıyla, ders çalışma sıklığının YDÖKÖ puanlarının tamamını düşük düzeyde etkilediği belirtilebilir.

\section{Lise Öğrencilerinin İngilizce ile İlgili Öz Yeterlik İnançları İle Yabancı Dil Öğrenme Kaygıları Arasındaki İlişkinin İncelenmesine İlişkin Bulgular}

Lise öğrencilerinin öğretmenlerinin İngilizce ile ilgili öz yeterlik algıları ile yabancı dil öğrenme kaygıları arasındaki ilişkiye yönelik Pearson Korelasyon analizi sonuçları Tablo 13'te verilmiştir.

Tablo 13. Lise Öğrencilerinin İngilizce ile İlgili Öz Yeterlik Algıları ile Yabancı Dil Öğrenme Kaygıları Arasındaki İlişkinin Belirlenmesine Yönelik Pearson Korelasyon Analizi Sonuçları

\begin{tabular}{lccc}
\hline \multicolumn{1}{c}{ Ölçekler } & $\boldsymbol{N}$ & Pearson $\boldsymbol{R}$ & $\boldsymbol{p}$ \\
\hline İïÖYÏÖ* YDÖKÖ & 686 & -.504 & $.000^{*}$ \\
\hline${ }^{*} \mathrm{p}<.05$ & & &
\end{tabular}


Tablo 13 incelendiğinde, lise öğrencilerinin İngilizce ile ilgili öz yeterlik algıları ile yabancı dil öğrenme kaygıları arasında orta düzeyde ve zıt yönlü bir ilişki olduğu görülmektedir (Pearson $\mathrm{R}=-.504, \mathrm{p}<.001$ ). Buna göre; lise öğrencilerinin İngilizce ile ilgili öz yeterlik algıları arttıkça yabancı dil öğrenmeye yönelik kaygılarının azaldığı; İngilizce ile ilgili öz yeterlik algıları azaldıkça da yabancı dil öğrenme kaygılarının arttığı ifade edilebilir.

\section{SONUÇ, TARTIŞMA VE ÖNERILLER}

\section{Sonuc}

1. Araştırmadan elde edilen sonuçlara göre, cinsiyet değişkeninin lise öğrencilerinin İngilizce öz yeterlik algılarında genel olarak belirleyici bir etkiye sahip olmadığ belirlenmiştir.

2. Araştırmada sınıf düzeyinin lise öğrencilerinin İngilizce ile ilgili öz yeterlik algılarında etkili olduğu; 9 ve 10. sınıfta öğrenim gören öğrencilerin İngilizce öz yeterlik algılarının 11 ve 12. sınıfta öğrenim gören öğrencilerden daha yüksek olduğu sonucuna varılmıştır.

3. Araştırmada aile gelir düzeyinin lise öğrencilerinin İngilizce ile ilgili öz yeterlik algıları üzerinde genel olarak etkili olduğu; aile gelirleri $5001 \mathrm{TL}$ ve üzerinde olan ögrencilerin İngilizce öz yeterlik algılarının aile gelirleri daha az olan öğrencilerden yüksek olduğu sonucu elde edilmiştir.

4. Araştırmada herhangi bir yabancı dil kursuna katılma durumunun lise öğrencilerinin İngilizce öz yeterlik algılarını etkilediği sonucuna ulaşılmıştır. Kursa katılan öğrencilerin öz yeterlik algılarının katılmayan öğrencilere kıyasla daha yüksek olduğu sonucuna varılmıştır.

5. Araştırmada İngilizce dersine çalışma sıklığının lise öğrencilerinin İngilizce öz yeterlik algılarında etkili olduğu; İngilizce dersine çalışma sıklığı arttıkça öz yeterlik algısının da arttığı sonucuna varılmıştır.

6. Araştırmada cinsiyet değişkeninin yabancı dil öğrenme kaygısı ölçeğinin tamamını ve iletişim alt boyutunu etkilediği; kadın öğrencilerin yabancı dil öğrenme kaygılarının erkek öğrencilere kıyasla daha yüksek olduğu belirlenmiştir.

7. Araştırmada sınıf düzeyinin lise öğrencilerinin yabancı dil öğrenme kaygısı üzerinde etkili olduğu sonucuna varılmıştır. 9, 10 ve 11 . sınıfta öğrenim gören öğrencilerin yabancı dil öğrenme kaygılarının 12. sınıfta öğrenim gören öğrencilerden daha yüksek olduğu, en yüksek kaygının da 10 ve 11. sınıflarda öğrenim gören ögrencilerde olduğu belirlenmiştir. 
8. Araştırmada aile gelir düzeyinin lise öğrencilerinin yabancı dil öğrenme kaygıları üzerinde belirleyici bir etkiye sahip olmadığı sonucuna varılmıştır.

9. Araştırmada herhangi bir yabancı dil kursuna katılma durumunun lise öğrencilerinin yabancı dil öğrenme kaygıları üzerinde genel olarak etkili olduğu sonucuna ulaşılmıştır. Kursa katılmayan öğrencilerin yabanc1 dil öğrenme kaygılarının katılan öğrencilere kıyasla daha yüksek olduğu belirlenmiştir.

10. Araştırmada İngilizce dersine çalışma sıklığının lise öğrencilerinin yabancı dil öğrenme kaygılarını etkilediği; İngilizce dersine çalışma sıklığı azalan öğrencilerin kaygılarının da arttı̆̆ sonucuna varılmıştır.

11. Araştırmada, lise öğrencilerinin İngilizce ile ilgili öz yeterlik algıları arttıkça yabancı dil öğrenmeye yönelik kaygılarının azaldığı; İngilizce ile ilgili öz yeterlik algıları azaldıkça da yabancı dil öğrenme kaygılarının arttığı sonucuna ulaşılmıştır.

\section{Tartışma}

Araştırmanın sonucunda lise öğrencilerinin İngilizce ile ilgili öz yeterlik algılarının cinsiyetten etkilenmediği belirlenmiştir. Alanyazında araştırmanın sonucuyla paralellik gösteren pek çok çalışmaya rastlanmıştır. Gömleksiz ve Kılınç (2014) yaptıkları çalışmada cinsiyet değişkenine göre öğrencilerin İngilizce öz yeterlik inançlarında anlamlı farklılık bulamamışlardır. Fakat Aykaç Duman (2007) tarafından yürütülen lise öğrencilerinin öz yeterlik inanc1 puanlarının cinsiyet değişkeni açısından incelendiği çalışmada kız öğrencilerin öz yeterlik inançlarının erkek öğrencilere göre daha yüksek olduğu bulgusuna erişilmiştir. Bunun farklılığın nedeni araştırmaların gerçekleştirildiği yerler arasındaki kültürel ve sosyal farklılıklar olabilir. Bir başka neden olarak örneklem gruplarının yaş faktörü açısından birbirinden farklılaşması gösterilebilir.

Lise öğrencilerinin İngilizce öz yeterlik algıları sınıf değişkeni açısından incelendiğinde 9 ve 10. sınıf öğrencilerinin İngilizceye yönelik öz yeterlik algılarının 11 ve 12. sınıf öğrencilerinden daha yüksek olduğu belirlenmiştir. $\mathrm{Bu}$ sonuç İngilizce dersinin içeriğinin ve konularının 11 ve 12. sınıfta 9 ve 10. sınıfa kıyasla daha yoğun ve karmaşık hale gelmesi, 11 ve 12. sınıfta öğrenim gören öğrenciler üniversite sınavına odaklandıklarından dolayı İngilizce gibi bazı derslere yoğunlaşamıyor olabilecekleri ve dolayısıyla da öz yeterlik algılarında düşüş olabileceği şeklinde yorumlanabilir. Urhan (2013) ve Gürbüztürk ve Şad (2009) yaptıkları çalışmalarında, sınıf düzeyi değişkenine göre öz yeterlik algısının anlamlı farklılaştığını tespit etmiştir. Benzer şekilde Aykol'un (2017) çalışmasının sonucunda sınıf düzeyi değişkenine göre İngilizce öz yeterlik algısı 9. sınıfların lehine anlamlı farklılık çıkmıştır. 
Lise öğrencilerinin İngilizce öz yeterlik algıları aile gelir düzeyi açısından incelendiğinde, aile geliri $5001 \mathrm{TL}$ ve üzerinde olan öğrencilerin aile gelir düzeyi daha az olan öğrencilere kıyasla İngilizce öz yeterlik inançlarının daha yüksek olduğu sonucuna ulaşılmıştır. Bunun nedeni olarak maddi gelirin yükselmesiyle öğrencilerin kaynaklara ulaşmasının kolaylaşması, okul derslerine ek olarak yabancı dil kurslarına gidebilme imkânlarının artması gösterilebilir. Satıcı (2013) ekonomik durumun iyi olmasının bireylerin yaşam standartlarının yükselmesine katkıda bulunacağını, yüksek yaşam standartlarına sahip bireylerin de kendilerini geliştirebilecekleri ortamlarda daha fazla bulunacağını belirtmektedir. Bunun yanı sıra eğitim ihtiyaçlarına giderebilmek için ellerine daha çok firsat geçebileceğini ve daha fazla eğitsel yaşantı geçirerek akademik öz yeterliklerini de yüksek seviyelere çıkarabileceklerini ifade etmektedir.

Lise öğrencilerinin İngilizce öz yeterlik algıları herhangi bir İngilizce kursuna katılma durumu açısından incelendiğinde, İngilizce kursuna katılan öğrencilerin İngilizce öz yeterlik inançlarının katılmayan öğrencilere kıyasla daha yüksek olduğu sonucuna ulaşılmış̧ır. Bu bulgudan herhangi bir İngilizce kursuna katılan öğrencilerin okuldaki İngilizce derslerinde öğretilenlere ek olarak kursta da takviye ders aldıklarından dolayı katılmayan öğrencilere kıyasla daha fazla mesafe almış olabilecekleri, İngilizce dersine daha fazla vakit harcadıkları ve dolayısıyla daha iyi seviyede oldukları çıkarılabilir. Baysal (2018) da özel kurumların gramer ve kelime bilgisinin dışında öğrencilere iletişim kurabilecekleri ortamları sağlayabileceğini, öğrencilerin çeşitli öğrenme ve öğretme stratejilerini kullanarak İngilizce pratiğinde zenginleşme imkânına sahip olabileceklerini ifade etmektedir.

Lise öğrencilerinin İngilizce öz yeterlik algıları İngilizce dersine çalışma sıklığı açısından incelendiğinde, her gün, haftada bir, ayda bir ve birkaç ayda bir İngilizceye çalışan öğrencilerin İngilizce öz yeterlik algılarının hiç çalışmayan ögrencilere kıyasla daha yüksek olduğu sonucu elde edilmiştir. Buradan hareketle öğrencilerin İngilizce dersine harcadıkları zamanın artmasıyla birlikte ders başarılarının artmış olabileceği ve dolayısıyla da derse yönelik öz yeterlik algılarının artabileceği sonucu çıkarılabilir.

Lise öğrencilerinin yabancı dil öğrenme kaygılarının cinsiyet değişkeni açısından incelenmesi sonucunda, kadın öğrencilerin yabancı dil öğrenme kaygılarının erkek öğrencilerden daha yüksek olduğu belirlenmiştir. Buradan kadın öğrencilerin erkek öğrencilere kıyasla daha çekingen olmaları ve bundan dolayı özellikle yabancı dil derslerinin iletişim boyutunda bunun yansımalarının olabileceği sonucu çıkarılabilir. Dolayısıyla çekingen davranışlar derse aktif katılımı olumsuz etkilemiş olabilir ve bu da yabancı dil dersine yönelik kaygının artmasına neden olabilir. Ayrıca Çakıcı'nın (2015) ifade ettiği gibi cinsiyet değişkeniyle ilgili bu sonuçtan kız öğrencilerin iletişim korkusunu, sınanma 
korkusunu ve olumsuz değerlendirilme korkusunu daha yoğun olarak yaşadıkları, erkeklerin ise stresle başa çıkabildikleri ve yabancı dilin konuşma boyutunda kendilerine kız öğrencilerden daha fazla güvendikleri yorumları çıkarılabilir.

Lise öğrencilerinin yabancı dil öğrenme kaygıları sınıf düzeyi açısından incelendiğinde 9,10 ve 11. sınıf öğrencilerinin yabancı dil öğrenme kaygılarının 12. sınıf öğrencilerinden daha yüksek olduğu sonucuna ulaşılmıştır. Yabancı dil öğretim programlarının 9. sınıftan itibaren yoğunlaşmaya başlaması ve konuların daha da zorlaşmaya başlaması 9. sınıftan itibaren lise öğrencilerinin yabancı dile yönelik kaygılarının artmasına neden olmuş olabilir. Ancak 12. sınıf öğrencilerinin kaygıları okul derslerinden ziyade üniversite sınavına yönelik olmaya başlar. Bundan dolayı 12. sınıfta öğrenim gören öğrencilerin yabancı dile yönelik kaygıları diğer sınıf düzeyindeki öğrencilere kıyasla daha düşük olabilir.

Lise öğrencilerinin yabancı dil öğrenme kaygıları aile geliri değişkeni açısından incelendiğinde maddi gelir düzeyinin lise öğrencilerinin yabancı dil öğrenme kaygılarını etkilemediği sonucuna ulaşılmıştır. Her geçen gün bilgi daha ulaşılabilir hale gelmektedir. Teknolojik cihazların günlük hayatta ve eğitim ortamında kullanımının artması ve İnternetin yaygın hale gelmesiyle birlikte bilgi parmaklarımızın ucu kadar yakınımızdadır. Bu noktada bilgi gelir seviyesi ne olursa olsun her öğrenciye eşit uzaklıktadır. Yabancı dil öğrenimi açısından da benzer şeyler ileri sürülebilir. Öğrencilerin İnternet ve teknolojik cihazlar vasıtasıyla ulaşabilecekleri çok fazla doküman vardır. Bu dokümanlar sayesinde maddi geliri farklı olan öğrencilerin kaynaklara ulaşmaları hususundaki mesafe gitgide azalmış olabilir ve dolayısıyla da bu da yabancı dile yönelik kaygılarını da etkilemiş olabilir. Araştırmanın bulgusuna benzer şekilde Çimen (2011) de çalışmasında ailelerin aylık gelir düzeylerine göre öğrencilerin İngilizce kaygıları arasında istatistiksel anlamlı bir fark bulamamıştır.

Lise öğrencilerinin yabancı dil öğrenme kaygıları herhangi bir yabancı dil kursuna katılma durumu açısından incelendiğinde herhangi bir yabancı dil kursuna katılmayan öğrencilerin yabancı dil öğrenme kaygılarının katılan öğrencilere kıyasla daha yüksek olduğu sonucuna ulaşılmıştır. Buradan hareketle herhangi bir yabancı dil kursuna giden öğrencilerin yabancı dildeki yetkinlik seviyeleri artabilir ve dolayısıyla yabancı dildeki kaygılarının azalmasına neden olabilir. Bu nedenle de yabancı dil kursuna giden ile gitmeyen öğrenciler arasında yabancı dil kaygısı açısında farklılık oluşabilir. Alanyazında bu bulguyla benzerlik gösteren çalışmalar vardır. Tokur (2016) araştırmasında öğrencilerin yabancı dil kursuna katılıp katılmadıklarına göre yabancı dile yönelik kaygı puanları arasında anlamlı bir farklılık olduğunu ifade etmiştir. Okul, Hafçı ve Öncüer Çivici (2017) ve Arifova (2019) yürüttükleri çalışmalarda araştırmanın bulgusunun aksine bulgulara erişmişlerdir. 
Lise öğrencilerinin yabancı dil öğrenme kaygısı ders çalışma sıklığı değişkeni açısından incelendiğinde yabancı dil dersine haftada bir çalışan, ayda bir çalışan, birkaç ayda bir çalışan ve dersine hiç çalışmayan öğrencilerin her gün çalışan öğrencilere kıyasla yabancı dil öğrenme kaygılarının daha yüksek olduğu sonucuna varılmıştır. Yabancı dil dersine harcanan zamanın arttıkça ders başarısı da aynı oranda artabilir. Dolayısıyla ders başarısı artan öğrencilerin derse yönelik kaygıları da azalabilir. Bunu destekler nitelikte Batumlu ve Erden (2007) çalışmalarında başarısız öğrencilerin kaygı düzeylerinin başarılı olanlara göre daha yüksek olduğu bulgusuna erişmişlerdir. Alanyazında araştırmanın bulgusuna benzer sonuçlara ulaşan çalışmalara da rastlanmaktadır. Tokur (2016) çalışmasında öğrencilerin yabancı dil kaygılarının yabancı dil dersini çalışma sıklığı değişkenine göre anlamlı bir farklılık gösterdiği görülmektedir.

Araştırmada lise öğrencilerinin İngilizceye yönelik öz yeterlik algıları ile yabanc1 dil öğrenme kaygıları arasında orta seviyede, doğrusal ve zit yönde anlamlı bir ilişkinin olduğu sonucuna ulaşılmıştır. Buna göre; lise öğrencilerinin İngilizce ile ilgili öz yeterlik algıları arttıkça yabancı dil öğrenmeye yönelik kaygılarının azaldığı; İngilizce ile ilgili öz yeterlik algıları azaldıkça da yabancı dil öğrenme kaygılarının arttığı ifade edilebilir. Alanyazında öz yeterlik algıları ile yabancı dil kaygısı arasında negatif yönde korelasyon olduğuna işaret eden pek çok araştırma vardır (Anyadubalu, 2010; Cheng, 2001; Çimen, 2011; Demir, 2018; Erkan ve İflazoğlu Saban, 2011; Ghonsooly ve Elahi, 2010; Oğuz ve Akkaş Baysal, 2015; Tsai, 2013). Öğrencilerin yabancı dil öğrenmeye yönelik kaygıları, İngilizce öz yeterlik inançlarının negatif yönde anlamlı bir tahmincisidir. Öğrencilerin yabancı dil öğrenme kaygıları İngilizce ile ilgili öz yeterlik inancındaki değişmenin anlamlı bir açıklayıcısıdır. Öğrencilerin yabancı dil öğrenme kayg1 seviyeleri yükselirse öz yeterlik inancı da azalma şeklinde değişecektir. Bireylerin dil öğrenmede yaşadıkları kaygının devam etmesi, öz yeterlik seviyelerinin düşmesine ve öğrenme sürecindeki başarısızlığa ya da aksamalara yol açabilir (Orakcı, Aktan ve Toraman, 2019). Bu aksaklıkların ve başarısızlıkların önünün alınabilmesi için kaygıya neden olan durumların tespit edilmesinin yabancı dil öğretimi açısından önemli olduğu düşünülmektedir. Çünkü yüksek düzeyde yabancı dil kaygısı yabancı dil derslerinde başarısızlığa neden olabilmekte ve dolayısıyla da öz yeterlik algısında da düşüşe yol açabilmektedir.

Sonuç olarak, yabancı dil kaygısının başarıya olumlu katkısı olacak şekilde ideal bir düzeyde tutulması yabancı dil derslerine fayda sağlayabilir. Bunun için yabancı dil derslerinin etkinliklerle daha eğlenceli hale getirilmesi, öğrencilerin öğrenme eyleminin içine dâhil edilmeleri, onları güdüleyici dönütlerle başarı duygusunu yaşamalarının sağlanması önem arz etmektedir. 


\section{Öneriler}

Araştırmadan elde edilen sonuçlardan yola çıkarak uygulayıcılara ve araştırmacılara yönelik aşağıdaki öneriler ileri sürülebilir:

\section{Uygulayıcılara Yönelik Öneriler}

- Araştırmada kadın öğrencilerin İngilizce dersi konuşma boyutunda erkek öğrencilere oranla daha düşük öz yeterlik algısına sahip oldukları sonucuna varılmıştır. $\mathrm{Bu}$ sebeple İngilizce derslerinde kadın öğrencilerin derse aktif katılımlarının sağlanması, etkinliklere dâhil olmalarının sağlanması, onları güdüleyici dönütler verilmesi özellikle dersin konuşma boyutuna yönelik öz yeterlik algılarının yükselmesini sağlayabilir.

- İngilizce ile ilgili öz yeterlik algıları diğer sınıflara göre daha düşük olduğu belirlenen 11 ve 12. sınıf öğrencilerinin gerek üniversitede öğrenim görülen bölümlerde gerekse de üniversite bittikten sonraki iş hayatı boyunca yabancı dilin sağlayacağ1 avantajlar hususunda bilinçlendirilmeleri bu derslere yönelik öz yeterlik algılarının yükselmesine katkı sağlayabilir.

- Ailesinin maddi geliri daha yüksek olan öğrencilerin aile maddi geliri daha düşük öğrencilere kıyasla İngilizceye yönelik öz yeterlik algılarının daha yüksek olduğu dikkate alınırsa, öğrencilerin teknolojik cihazlar ve İnternet aracılığıyla erişebilecekleri kaynaklar ve uygulamalar konusunda bilgilendirilmesi bu farklılaşmanın azalmasına neden olabilir ve maddi geliri daha düşük olan öğrencilerin de öz yeterlik algılarında artış sağlanabilir.

- Yabancı dil öğrenim sürecinde yabancı dil öğrenme kaygısının olumsuz etkileri göz önünde bulundurulursa (Eke, 2019), öğrenme ortamlarının rekabetten uzak hale getirilmesi, demokratik bir sınıf ortamının sağlanması, öğrenmenin eğlenceli, anlamlı ve kalıcı hale getirilmesiyle yabancı dil öğrenme kaygısının olumsuz etkilerinin ortadan kaldırılması sağlanabilir.

\section{Araştırmacılara Yönelik Öneriler}

- Bu araştırma lise öğrencilerinin İngilizce ile ilgili öz yeterlik algıları ve yabancı dil öğrenme kaygılarını incelemek amacı ile yapılmıştır. Benzer çalışma farklı eğitim kademelerindeki öğrencilerle gerçekleştirilebilir.

- Bu araştırma bir Anadolu lisesinde öğrenim gören öğrenciler ile yürütülmüştür. Benzer çalışma farklı liselerde öğrenim gören öğrenciler ile gerçekleştirilebilir ve farklı liselerdeki öğrencilerin İngilizce öz yeterlik algıları ile yabancı dil ögrenme kaygıları karşılaştırılabilir. 
- Bu araştırmada lise öğrencilerinin İngilizce ile ilgili öz yeterlik algıları ve yabancı dil öğrenme kaygıları arasındaki ilişki cinsiyet, sınıf düzeyi, aile geliri, yabancı dil kursuna katılma durumu ve ders çalışma sıklığı değişkenleri açısından incelenmiştir. Benzer çalışma ders başarısı, anne eğitim durumu, baba eğitim durumu, lise türü gibi farklı değişkenlerle gerçekleştirilebilir.

- Araştırma sadece lise öğrencileri ile yürütülmüştür. Farklı bir çalışmada İngilizce öğretmenlerinin öz yeterlik algıları ile bu öğretmenlerin öğrencilerine ait İngilizce öz yeterlik algıları beraberce incelenebilir.

- Araştırmada veri toplama aracı olarak ölçekler kullanılmış olup nicel bir araştırma özelliğindedir. Farklı bir araştırmada sınıf içinde öğretmen ve öğrenci davranışları gözlemlenerek öğrencilerin yabancı dil öğrenme kaygılarına neden olan ve öz yeterlik algılarını olumsuz etkileyen faktörler ortaya konulabilir.

- Farklı öğretim yöntemleri ile gerçekleştirilen yabancı dil derslerinin öğrencilerin İngilizce öz yeterlik algılarına ve yabancı dil öğrenme kaygılarına etkisini inceleyen deneysel bir araştırma gerçekleştirilebilir.

- Bu çalışmada öğrencilerin yabancı dille ilgili öz yeterlik algısı ve kaygıları betimsel yaklaşımla incelendiğinden dolayı yabancı dil öğretimi ve öğreniminde kaygıya neden olan etkenlerin belirlenmesi ve bu etkenlerin azaltılmasına yönelik yapılacak çalışmalar yabancı dil öğrenme sürecine olumlu katkı sağlayabilir.

- Farklı bir araştırmada öğretmenlerin öğretme motivasyonları ile öğrencilerin yabancı dile yönelik kaygıları incelenebilir.

\section{KAYNAKÇA}

Aida, Y. (1994). Examination of horwitz, horwitz, and cope's construct of foreign language anxiety: The case of students of Japanese. The Modern Language Journal, 78, 155-168.

Alc1, B. ve Yüksel, G. (2012). An examination into self-efficacy, metacognition and academic performance of pre-service ELT students: Prediction and difference, Kalem Eğitim ve Insan Bilimleri Dergisi, 2(1), 143-165.

Andrade, M. ve Williams, K. (2009). Foreign Language Learning Anxiety in Japanese EFL University Classes: Physical, Emotional, Expressive, and Verbal Reactions", Sophia Junior College Faculty Journal, 29, 1-24.

Anyadubalu, C. C (2010). Self-Efficacy, anxiety, and performance in the english language among middle-school students in english language program in 
satri si suriyothai school, Bangkok. International Journal of Human and Social Sciences, 5(3), 193-198.

Arifova, R. (2019). Illkokul öğrencilerinin yabancı dil öğrenme kaygılarının incelenmesi, [Yüksek Lisans Tezi], Ege Üniversitesi.

Aydoğdu, Ç. (2014). The relationship between foreign language learning anxiety, attitude toward English language, language learning strategies and foreign language achievement, Yüksek Lisans Tezi, Atatürk Üniversitesi.

Aykaç D. B. (2007), Lise öğrencilerinin İngilizceye yönelik öz yeterlik alg1 puanlarının cinsiyete, alanlara ve farklı düzeylere göre ingilizce başarısını yordama gücü, [Yüksek Lisans Tezi], Yıldız Teknik Üniversitesi.

Aykol, N. (2017). Lise öğrencilerinin yabancı dile yönelik kalıplaşmış düşünceleri ve yabancı dil özyeterlik algılarının çeşitli değişkenler açısından incelenmesi. Yüksek Lisans Tezi, Afyon Kocatepe Üniversitesi.

Bandura, A. (1977). Self-Efficacy: Toward a Unifying Theory of Behavioral Change. Psychological Review, 84(2), 191-215.

Bandura, Albert (1982). Self-Efficacy Mechanism in Human Agency. American Psychologist, 37(2), 122-147.

Baş, G. (2013). Yabancı Dil Öğrenme Kaygısı Ölçeği: Geçerlik ve Güvenirlik Çalışmas1. Türkiye Sosyal Araştırmalar Dergisi, 17(2), 49-68.

Baş, G. (2014). Lise Öğrencilerinde Yabancı Dil Öğrenme Kaygısı: Nitel Bir Araştırma. Pamukkale Üniversitesi Ĕ̆itim Fakültesi Dergisi, 36, 101-119.

Batumlu, D. Z. ve Erden, M. (2007). Yıldız Teknik Üniversitesi yabancı diller yüksek okulu hazırlı öğrencilerinin yabancı dil kaygıları ile İngilizce başarıları arasındaki ilişki. Eğitimde Kuram ve Uygulama, 3(1), 24-38.

Baysal, S. (2018). Meslek yüksekokulu ögrencilerinin dil öğrenme stratejilerinin ve yabancı dile yönelik kalıplaşmış düşüncelerinin incelenmesi, [Yüksek Lisans Tezi], Kahramanmaraş Sütçü İmam Üniversitesi.

Burgucu, A. (2011). The Role of Motivation, Attitude and Anxiety in Learning English as a Foreign Language, [Yüksek Lisans Tezi], Kafkas Üniversitesi. 
Büyükduman, F. İ. (2006). Ingilizce ögretmen adaylarının İngilizce ve ögretmenlik becerilerine iliş̧kin öz-yeterlik inançları arasındaki iliş̧ki, Doktora Tezi, Yıldız Teknik Üniversitesi.

Büyüköztürk, Ş. (2018). Sosyal Bilimler İçin Veri Analizi El Kitabı, Pegem Akademi.

Chen, T. Y. and Chang, G. (2004). The Relationship Between Foreign Language Anxiety and Learning Difficulties. Foreign Language Annals, 37(2), 279289.

Cheng, Y.-S. (2001). Learners' Beliefs and Second Language Anxiety. Concentric: Studies in English Literature and Linguistics, 27(2), 25-90.

Cohen, J. (1988). Statistical Power Analysis for the Behavioral Science, Lawrence Erlbaum Associates, Inc., Publishers, New Jersey.

Cui, J. (2011). Research on high school students' English learning anxiety. Journal of Language Teaching and Research, 2(4), 875-880.

Çakıc1, D. (2015). Foreign language anxiety of prospective English Language Teachers. International Journal of Languages' Education and Teaching, 8, 495-507.

Çekirdek, G. (2014). Hazırlık sınıfı ögrencilerinin İngilizce başarılarını etkileyen bazı faktörlerin incelenmesi, [Yüksek Lisans Tezi], Osmangazi Üniversitesi.

Çimen, S. (2011). Eğitim fakültesi ögrencilerinin İngilizceye yönelik tutum, ingilizce kaygısı ve öz yeterlik düzeylerinin incelenmesi, [Yüksek Lisans Tezi], Karaelmas Üniversitesi

Demir, B. (2018), Yabancı dil hazırlık okulunda özyeterlik inancı ve yabancı dil öğrenme kaygısı arasındaki ilişki, [Yüksek Lisans Tezi], Çağ Üniversitesi.

Eke, H. A. (2019). Lise öğrencilerinin bilişüstü farkındalık düzeyleri, yabancı dil ögrenme inançları, yabancı dil öğrenme kaygıları arasındaki iliş̧kiler, Yüksek Lisans Tezi, Düzce Üniversitesi.

Ergüder, I. (2005). Anadolu lisesi ve süper lise hazırlık sınıfi öğrencilerinin Ingilizce öğreniminde karşılaştıkları sorunlar, [Doktora Tezi], Dokuz Eylül Üniversitesi.

Erkan, D. Y. and Iflazoğlu S., A. (2011). Writing performance relative to writing apprehension, self-efficacy in, writing and attitudes towards writing: A 
correlational study in Turkish tertiary-level EFL. The Asian EFL Journal Quarterly, 13(1), 163-191.

Foss, K. A. and Reitzel, A. C. (1988). A Relational Model for Managing Second Language Anxiety. Tesol Quarterly, 22(3), 437-454.

Ghonsooly, B. and Elahi, M. (2010) Learners' Self-Efficacy in reading and its relation to foreign language reading anxiety and reading achievement. Journal of English Language Teaching and Learning, 53(217), 45-67.

Gökdemir, C. V. (2005). Üniversitelerimizde verilen yabancı dil öğretimindeki başarı durumumuz. Atatürk Üniversitesi Sosyal Bilimler Enstitüsü Dergisi, 6(2), 251-264.

Gömleksiz, M. N. ve Kılınç, H. H. (2014). Lise 12. sınıf öğrencilerinin İngilizce öz yeterlik inançlarına ilişkin görüssleri. Fırat University Journal of Social Sciences/Sosyal Bilimler Dergisi, 24(2), 43-60.

Gülözer, A. (2010). Farklı test formatları ile ölçülen yabancı dil başarısının ögrencilerin tutumları, kaygı düzeyleri ve ögrrenme stilleri ile ilişkisinin incelenmesi, [Yüksek Lisans Tezi], Abant İzzet Baysal Üniversitesi.

Gürbüztürk, O. and Şad, S. N. (2009). Student teacher's belief about teaching and their sense of self-efficacy: A descriptive and comparative analysis, Inonu University Journal of The Faculty of Education, 10(3), 201-226.

Hancı Y. B. (2008). Yabancı dil hazırlık eğitimi alan ve almayan Anadolu lisesi ögrencilerinin yabancı dil öz yeterlik algılarının ve İngilizceye yönelik tutumlarının incelenmesi, [Yüksek Lisans Tezi], Ege Üniversitesi.

Hancı Y. B. ve Bümen, N. T. (2012). İngilizce ile ilgili özyeterlik inancı ölçeğinin geliştirilmesi. Kastamonu Eğitim Dergisi, 20(1), 97-110.

Horwitz, E. K, Horwitz, M. B ve Cope, J. (1986), Foreign language classroom anxiety. Modern Language Journal, 70(2), 125-132.

Hsieh, Pei-Hsieh (2008), "Why Are College Foreign Language Students' SelfEfficacy, Attitude, and Motivation So Different?", International Education, 38(1), ss. 76-94.

Hussain, M. A., Shahid, S.ve Zaman, A. (2011). Anxiety and attitude of secondary school students towards foreign language learning", Procedia Social and Behavioral Sciences, 29, 583-590. 
Kanadlı, S. ve Bağçeci, B. (2015). Öğrencilerin İngilizce öz yeterlik inançlarının algılanan özerklik desteği açısından incelenmesi. Mustafa Kemal Üniversitesi Sosyal Bilimler Enstitüsü Dergisi, 12(30), 98-12.

Karanfil, B. ve Arı, A. (2016). Yükseköğretim İngilizce hazırlık sınıflarında güç paylaşım düzeyi ile öğrencilerin İngilizce özyeterlik algıları arasındaki ilişkinin incelenmesi. Sakarya Üniversitesi Eğitim Fakültesi Dergisi, 32, 12-39.

Karasar, N. (2009). Bilimsel Araştırma Yöntemi, Nobel Yayın Dağıtım.

Köse, E. (2005), The Impact of Dialogue Journals on Language Anxiety and Classroom Affect. [Yüksek Lisans Tezi], Bilkent Üniversitesi.

Liu, H-J. ve Chen, C-W. (2015). A comparative study of foreign language anxiety and motivation of academic and vocational-track high school students. English Language Teaching, 8(3), 193-204.

Mills, N., Pajares, F. ve Herron, C. (2006). A reevaluation of the role of anxiety: self-efficacy, anxiety, and their relation to reading and listening proficiency. Foreign Language Annals, 39(2), 276-295.

Moore, K. (2007). Intercultural communication and foreign language anxiety, Yüksek Lisans Tezi, The Florida State University.

Na, Z. (2007). A study of high school students' english learning anxiety. The Asian EFL Journal, 9(3), 22-34.

Ocak, G. ve Akkaş B., E. (2016). Öğrencilerin dil öğrenme stratejileri ve İngilizce özyeterlik inançlarının incelenmesi: Afyonkarahisar ili örneği. Marmara Üniversitesi Atatürk Ĕ̆itim Fakültesi Eğitim Bilimleri Dergisi, 44(44), 91110.

Oğuz, A. ve Akkaş Baysal, E. (2015). Ortaöğretim öğrencilerinin İngilizce öğrenme kaygıları ile İngilizce öz yeterlik inançlarının incelenmesi. Ĕgitim ve Öğretim Araştırmaları Dergisi, 4(3), 111-117.

Okul, T., Hafçı, B. ve Öncüer Çivici, M., E. (2017). Yabancı dil öğrenme kaygısı: Adnan Menderes Üniversitesi Turizm Fakültesi öğrencileri üzerine bir uygulama. Mesleki Bilimler Dergisi, 6(2), 186-194.

Orakcı, Ş., Aktan, O. ve Toraman, Ç. (2019). Lise öğrencilerinin İngilizce özerklik algısı, kaygısı ve özyeterlik inancı arasındaki ilişkinin incelenmesi. Uluslararası Toplum Araştırmaları Dergisi, 11(18), 424-450. 
Sarıül, H. (2000). Trait anxiety or foreign language anxiety and their effects on learners' foreign language proficiency and achievement, [Yüksek Lisans Tezi], Boğaziçi Üniversitesi.

Satıcı, S. A. (2013). Üniversite ögrencilerinin akademik öz-yeterliklerinin çeşitli değişkenler açısından incelenmesi, [Yüksek Lisans Tezi], Anadolu Üniversitesi.

Todaka, Y. (2017). Self-Efficacy of English listening skills in japanese college EFL learners: Quantitative and qualitative analyses. European Journal of English Language Teaching, 2(1), 93-119.

Tokur, B. (2016). Anadolu Lisesi ögrencilerinin yabancı dil kaygılarının incelenmesi. [Yüksek Lisans Tezi], Dicle Üniversitesi.

Tsai, C. C. (2013). The İmpact of foreign language anxiety, test anxiety and selfefficacy among senior high school students in Taiwan. International Journal of English Language and Linguistics Research, 1(3), 1-17.

Urhan, İ. (2013). Türkçe ögrretmeni adaylarının yansıtıcı düşünme ile öğretmen öz yeterlik algısı arasındaki ilişkinin incelenmesi, Yüksek Lisans Tezi, Niğde Üniversitesi.

Ünal, F. (2016). Lise ögrencilerinin yabancı dil öğrenme kaygısı ile yabancı dil ögreniminde motivasyon tutumlarının incelenmesi (İstanbul - Kadıköy ilçesi örneği), [Yüksek Lisans Tezi], Yeditepe Üniversitesi.

Wörde, R. (2003). Students' Perspectives on foreign language anxiety. Inquiry, $8(1), 1-15$.

Yıldırım, A. ve Şimşek, H. (2016). Sosyal Bilimlerde Nitel Araştırma Yöntemleri, Seçkin Yayıncılık.

Young, D. J. (1990). An investigation of students' perspectives on anxiety and speaking. Foreign Language Annals, 23(6), 539-553. 